\title{
Learning Cycle Model Assisted by Audio Visual Increases Science Knowledge Competence
}

\author{
I Gusti Ayu Ita Purnamaningsih ${ }^{1}$, DB. Kt. Ngr. Semara Putra², I Wayan \\ Wiarta $^{3}$
}

${ }^{123}$ Program Studi Pendidikan Guru Sekolah Dasar, Fakultas Ilmu Pendidikan, Universitas Pendidikan Ganesha, Bali, Indonesia

\section{A R T I C L E I N F O Article history: \\ Received 2 Juni 2020 \\ Received in revised form 12 Juli 2020 \\ Accepted 10 Agustus 2020 \\ Available online 28 Agustus 2020}

\section{kata kunci:}

learning cycle, audio visual, IPA

keywords:

learning cycle, audio visual, science knowledge

\begin{abstract}
A B S T R A K
Rendahnya kompetensi pengetahuan IPA siswa yang disebabkan oleh kurang optimalnya penggunaan model pembelajaran yang inovatif serta kurangnya penggunanan media pembelajaran. Tujuan dari penelitian ini untuk menganalisis pengaruh yang signifikan model pembelajaran learning cycle berbantuan media audio visual terhadap kompetensi pengetahuan IPA Kelas IV SD. Jenis penelitian ini merupakan eksperimen semu dengan desain penelitian non-equivalent control group design. Sampel dalam penelitian ini menggunakan Teknik Cluster Random Sampling yaitu kelas IV dengan sebanyak 30 siswa sebagai kelompok eksperimen serta kelas IV sebanyak 31 siswa, sebagai kelompok kontrol. Populasi dalam penelitian ini yaitu seluruh siswa kelas IV sebanyak 257 siswa. Pengumpulan data kompetensi pengetahuan IPA dilakukan dengan metode tes dan instrumen yang digunakan berupa tes objektif pilihan ganda biasa. Data dianalisis menggunakan uji-t. Berdasarkan hasil analisis data nilai thitung $=3,184$ sedangkan pada taraf signifikansi $5 \%$ dan $\mathrm{dk}=59$ nilai tabel $=2,045$ sehingga
\end{abstract} thitung $=3,184>$ tabel $=2,045$. Berdasarkan kriteria pengujian, maka $H_{o}$ ditolak dan $H_{a}$ diterima. Terdapat perbedaan yang signifikan kompetensi pengetahuan IPA Antara kelompok kontrol serta kelompok eksperimen. Rata-rata kompetensi pengetahuan IPA siswa kelompok eksperimen dan kelompok kontrol yaitu 85,677 > 70,935. Jadi dapat disimpulkan, model pembelajaran Learning Cycle berbantuan media Audio Visual berpengaruh terhadap kompetensi pengetahuan IPA kelas IV SD.

\begin{abstract}
A B S T R A C T
The low ability of science knowledge competence was caused by less optimal use of innovative learning models and the lack of using instructional media. This study aimed to analyze the significant effect of the learning cycle model assisted by audiovisual media on the IPA knowledge competence of the fourth-grade students. The type of this study was a quasi-experimental research with the non-equivalent control group design. The samples in this study were determined using the Cluster Random Sampling technique where by fourth-grade with 30 students as an experimental group and fourth-grade with 31 students as a control group. The population in this study was all students in grade IV elementary school which has 257 students. The data of science knowledge competence were collected using the test method and the instrument used was an ordinary multiple-choice objective. The data were analyzed using a t-test. Based on the result of data analysis, the score of $t_{\text {count }}=3,184$ while at the significant level $5 \%$ and $\mathrm{dk}=59 \mathrm{t}_{\text {table }}=2,045$ so that $\mathrm{t}_{\text {count }}=3,184>\mathrm{t}_{\text {table }}=2,045$. Based on the testing criteria, then Ho was rejected and $\mathrm{Ha}$ was accepted. There were significant differences in the science knowledge competence between the group control and the experimental group. The average of science knowledge competence students in the experimental group and control group was 85,677 > 70,935. It can be concluded that the Learning Cycle model assisted by audiovisual media influences the science knowledge competence in the fourth-grade students of elementary school.
\end{abstract}

\section{Introduction}

One of the materials in the 2013 curriculum is science. The curriculum is defined by learnercentered learning activities (Amanda, 2017). This curriculum is determined to provide learning experiences to students. Students are asked to be more proactive and creative. One of the competencies that need to be developed is the competence of science knowledge. Science is learning based on principles and processes in developing scientific attitudes (Astuti, 2017). Science is related to the symptoms that occur in the natural world by studying science which can develop students' scientific attitudes. IPA examines natural events that are structured based on observations of an object using appropriate procedures so that they can come up with reasoning and be able to provide

Corresponding author.

Copyright (C) Universitas Pendidikan Ganesha. All rights reserved. wayanwiarta@gmail.com ${ }^{3}$ (Wayan Wiarta) 
a conclusion (Pradnyandari, 2014). Science is a science that studies about natural phenomena that have been systematically compiled based on observations and experiments (Muakhirin, 2014).

Science learning should make students active and make students discover the material being studied for them self, where the learning process is centered on students, not on the teacher. There is no interaction between students and teachers; students tend to be less interested in science lessons. These constraints will certainly affect science knowledge competence. When the learning process takes place with the dominant teacher plays an active role in the learning process, student teacher-centered learning only becomes the listener. Teachers need to use a variety of learning models and use learning media so that students do not get bored in participating in learning. The quality of education will not be good if it is not supported by the existence of media that play a role in learning material easily (Karunia, 2017). There are other obstacles experienced by students such as the large number of science material that is difficult for students to understand so that more students memorize science material rather than understand it. Science studies a lot about things that are still abstract, so students find science learning difficult and boring (Barus, 2019). The lack of learning innovation is an obstacle in the learning process (Taung, 2014). Science learning in class tends to be taught conventionally, explanation verbally and giving monotonous tasks (Devitasari, 2019). Conventional learning is teacher-centered learning. In general, the characteristics of conventional learning according to (Agung, 2014) are: a) students are receiving information passively, b) learning is very abstract and theoretical, c) behavior is built on habits, d) truth is absolute and knowledge is final, e) the teacher determines the course of the learning process, f) good behavior based on extrinsic motivation, g) teacher-centered and $h$ ) learning is mechanistic.

This problem also occurred in SDN Gugus VIII Mengwi. The learning process and the results of the competency in science knowledge are not as expected. This is evidenced by the results of observations and interviews conducted on Monday, October 20 2019, in the fourth grade of SDN Gugus VIII Mengwi. Each student experiences difficulties in carrying out the different learning processes. For competency knowledge on the content of science material obtained from the MidSemester Assessment as follows.

Table 1. Science learning UTS score at SDN Gugus VIII Kecamatan Mengwi

\begin{tabular}{|c|c|c|c|c|c|c|}
\hline No & Nama Sekolah & Kelas & KKM & $\begin{array}{c}\text { Jumlah } \\
\text { Siswa }\end{array}$ & $\begin{array}{l}\text { Jumlah } \\
\text { Siswa di } \\
\text { bawah } \\
\text { KKM }\end{array}$ & $\begin{array}{c}\text { Jumlah Siswa } \\
\text { di atas KKM }\end{array}$ \\
\hline 1 & SDN 1 MENGWI & IV & 70 & 39 & 21 & 18 \\
\hline 2 & SDN 2 MENGWI & IV & 70 & 23 & 17 & 6 \\
\hline \multirow[t]{3}{*}{3} & SDN 3 MENGWI & IVa & 70 & 25 & 18 & 7 \\
\hline & & $\mathrm{IVb}$ & 70 & 25 & 17 & 8 \\
\hline & & IVc & 70 & 27 & 18 & 9 \\
\hline \multirow[t]{2}{*}{4} & SDN 4 MENGWI & IVa & 70 & 21 & 16 & 5 \\
\hline & & $\mathrm{IVb}$ & 70 & 20 & 16 & 4 \\
\hline 5 & SDN 1 WERDHI BHUWANA & IV & 70 & 31 & 17 & 14 \\
\hline 6 & SDN 2 WERDHI BHUWANA & IV & 70 & 30 & 25 & 5 \\
\hline \multirow[t]{2}{*}{7} & SDN 3 WERDHI BHUWANA & IV & 70 & 15 & 9 & 6 \\
\hline & TOTAL & & & 257 & 174 & 110 \\
\hline
\end{tabular}

This is because the teacher does not use a variety of learning models and media. To create a pleasant learning atmosphere, it is necessary to have a learning process using models and media that make students active in every learning process. In choosing a learning model and learning media, it is adjusted to the characteristics possessed by students so that the learning process is effective (Dewi, 2018). From this statement, the Learning Cycle model is applied. The learning cycle is a series of activity stages that are organized in such a way that learning participants can master the number of competencies that must be achieved in learning through the role of student activities (Nismalasari, 2016). The Learning Cycle learning model is student-centered (Barahudin, 2014). The Learning Cycle learning model has 5 stages consisting of the first stage of generating interest, at this stage the teacher tries to arouse and develop students' interest and curiosity (Sulthon, 2012). In the learning process, each stage in the Learning Cycle learning model can arouse student interest and activity in participating in science learning which has a series of stages (phases) in learning activities by taking an active role. The cycle learning model is a natural way of learning and fulfilling the main educational 
goal of students learning how to think. The Learning Cycle learning model is in accordance with Piaget's theory, a constructivism-based theory where knowledge is built by students themselves through their experiences in an active way in the learning process (Dewi, 2017). Learning Cycle is a learning model that allows students to take part in active learning by applying the concepts that have been learned in new situations.

The advantages of the Learning Cycle model are improving students' scientific attitudes, inviting all students to be active in learning activities, and learning becomes more meaningful (Rahayu, 2019). The Learning Cycle learning model has five (Rahayu, 2019) stages: 1) Interest Generation, this stage aims to determine the initial abilities of students. At this stage, the teacher invites students to prepare for learning to the next stage by making estimates about what will be studied and proven in the exploration stage. Furthermore, the teacher will link learning with everyday life. 2) Exploration In exploration activities, students form small groups without direct teaching by the teacher. Individual students will be educated to develop their thinking because of the time to think and can perfect their conceptions through class discussion activities (Setiawan, 2017). Students are asked to test the conclusions that have been made and make new conclusions. The purpose of this phase the teacher wants to know the knowledge possessed by students. 3) Explanation. At this stage, the teacher asks students to explain the concepts they already have in their sentences. When carrying out the discussion, students are asked to find their concepts as the basis for the discussion. 4) Development. In this stage, students develop the concepts they have in new situations. Thus, students will learn meaningful and can be remembered for a long time by students because they have applied the new concepts they learn in new situations. 5) Evaluation is the final stage of the Learning Cycle learning model. At this stage, the teacher provides an assessment of students during learning by giving tests to measure the ability of students to understand the knowledge that has been conveyed by the teacher.

The Learning Cycle learning model will be combined with audiovisual media. (Wijayanti, 2017) Audio Visual Media is a media that can display images and sound so that it can attract the attention of students in following the learning process. Audio-visual media has better capabilities because it includes two elements, sound and image elements (Suryani, 2017). Students are very interested in audio-visual media because this media is something that can be observed, heard, and experienced directly. After all, it can create a meaningful impression in individual students (Saharudhin, 2018). The advantages of using audiovisual media are for the delivery of the teacher to explain the complex to the simple, can be used for classical or individual use, and can be used repeatedly (Rositayani, 2018). Audiovisual media is a form of learning media that is cheap and affordable (Kusuma, 2018). The advantages of this media are that it can display images and sounds that can be heard by students, not only that audio-visual media can cause interest or attention that causes joy in students, which in turn will bring interest and satisfaction to students. If students are interested in taking part in learning, it will have an optimal impact on the competence of science knowledge.

Theoretically, the Learning Cycle learning model assisted by audio-visual media has an effective impact on learning success. There are several relevant research results which reinforce that the Learning Cycle model assisted by audio-visual media has a positive impact on student learning success, including: 1) (Nurbani, 2016) stated that Learning Cycle learning on the relationship between the nature of the material and its use can improve students' science process skills significantly, 2) (Suarni, 2013) stated that the Learning Cycle learning model affects the fourth grade science learning outcomes, but there is something different, media based on environmental media, 3) (Dewi, 2013) There is an effect of the Learning Cycle learning model on fifth grade science learning outcomes but there are differences, not assisted with learning media, 4) (Aditya, 2019) there is an influence of the Learning Cycle learning model on learning discipline attitudes and science learning outcomes but there are differences, not assisted by learning media, 5) (Putriani, 2016) there is an influence of the learning model as a Learning Cycle to fifth grade student learning outcomes but there is a difference, not assisted learning media using graphic media.

From the explanation that has been conveyed, it is necessary to carry out related research to improve the competence of SD science knowledge by implementing an Audio Visual Media Assisted Learning Cycle Learning Model. So a study entitled "The Effect of Learning Cycle Learning Model Assisted by Audio-Visual Media on the fourth-grade science competency of SDN Gugus VIII, Kecamatan Mengwi. Based on this explanation, the purpose of this study was to determine the significant effect of the Learning Cycle learning model assisted by audio-visual media on the competence of science knowledge at SDN Gugus VIII, kecamatan Mengwi. This study is different from 
existing research; this research is assisted by audio-visual media. By applying this model and media, it is hoped that it can solve the problems that exist in SDN Gugus VIII, kecamatan Mengwi.

\section{Research Method}

The research method is a step taken to collect the data that has been obtained. This type of research is a quantitative study with an experimental design that is a quasi-experimental (quasiexperimental). (Sugiyono, 2018) The experimental method is a quantitative method, which can be used to determine the effect of independent and dependent variables under different control conditions. This research is categorized into experimental research because in this study the manipulation and control of the variables were deliberately carried out. This research design has two groups, the experimental group and the control group. The experimental design used in this study is the non-equivalent control group design. The experimental group was given learning treatment using the Learning cycle model assisted by audio-visual media, while the control group was treated by using conventional learning. At the end of the study, the two groups were given a posttest to find out whether there was a difference between the experimental group and the control group.

A population is a group of similar individuals who occupies a certain area. Population is an object that has a certain quantity and characteristics, in which conclusions are drawn (Sugiyono, 2018). The populations in this study were all fourth grade SD Negeri in Gugus VIII Mengwi for the $2019 / 2020$ school year totaling 257 students. After determining the research population, the next step is to determine the sample. The sample is part of the number and distinctive characteristics possessed by the population (Sugiyono, 2018). The sample is several small groups representing the population that can be used as research. The sampling technique in this study is the cluster random sampling technique. The cluster random sampling technique is carried out by mixing subjects in the population so that all subjects are considered the same and get the same rights. The randomization was done by randomizing the class and then doing a drawing. To find an equivalent class academically, a pretest was given for the sample. The t-test is a technique used to analyze pretest data before it must meet the criteria for the normality test and the homogeneity test. After conducting the equivalence test and the two groups were declared equal, it was continued by drawing the two groups to determine the experimental class and the control class. From the results of the drawing for the fourth grade SDN 2 Werdhi Buwana as the experimental group and the fourth-grade SDN 1 Werdhi Buwana as the control group.

In conducting the research, the test method was given to the samples both individually and in groups by answering several questions. The answers from each sample will get their respective scores. (Agung, 2014). So it can be concluded that the test is a tool used to measure or obtain data that must be done by someone. This regular multiple-choice test has 4 answer choices (a, b, c or d) with a total number of questions, 50 items. Each question gets a score of 1 if the question is answered correctly and if the question is answered incorrectly, it will get a score of 0 . The total score obtained from each answer is then added up, then the entire score becomes a competency score for science knowledge which has a range of $0-100$.

The preparation of tests is based on basic competencies (KD) and indicators that are following the subject matter. The KD and indicators used for the preparation of the instrument are presented in Table 2 below.

Table 2. Basic Competencies and Indicators of Science Knowledge Competency Instruments

\begin{tabular}{llc}
\hline \multicolumn{1}{c}{ Basic competency } & \multicolumn{1}{c}{ Indicator } & Cognitive type \\
\hline Identifying the types of forces, including: & Mention the various styles. & $\mathrm{C} 1$ \\
muscle force, electric force, magnetic \\
force, gravity force, and friction force. & & $\mathrm{C} 2$ \\
\cline { 2 - 3 } & $\begin{array}{l}\text { Give examples of the types of } \\
\text { forces, including: muscle force, } \\
\text { electric force, magnetic force, } \\
\text { gravity force, and friction force. }\end{array}$ & \\
\cline { 2 - 3 } & &
\end{tabular}




Identifying the types of forces,
including: muscle force, electric
force, magnetic force, gravity
force, and friction force.

Give examples of the benefits of
force in everyday life such as
muscle force, electric force,
magnetic force, gravity force,
and friction force.
Determine the benefits of force
in life
daily activities, such as muscle
force, electric force, magnetic
force, gravity force, and friction
force.

Demonstrating the benefits of force in everyday life, for example muscle force, electric force, magnetic force, gravitational force, and friction force.
Give examples of the benefits of force in everyday life such as and friction force.

Determine the benefits of force daily activities, such as muscle orce, electric force, magnetic force.

After that, the instrument testing is carried out. Before being tested, content validity and theoretical validity were first carried out and then tested as many as 50 items. The content validity test is carried out by direct testing of judges. Meanwhile, the test item validity uses the validity test, distinguishing power, difficulty level, and reliability. Many test items that met the requirements in the trial were 30 test items. So, the instruments used in this study have been validated and reliable.

The data analysis method used is inferential statistics. Inferential statistics are used to test the hypotheses proposed through the t-test of polled variance. However, before that, the prerequisite test was conducted first, the data normality test using the Kolmogorov-Smirnov test and the homogeneity test with the F test (Fisher).

\section{Result and Discussion}

There are two data obtained in this study, the posttest data on the competence of science knowledge by being taught with the Learning Cycle model assisted by Audio Visual media and the posttest results for the competency of the science knowledge of students who are not taught using the Learning Cycle model assisted by Audio Visual media. Based on this, the data in this study can be divided into two groups: 1). Science knowledge competency data of the experimental group. 2) Knowledge competency data of the control group.

Based on the results of the drawing, the experimental group used was the fourth-grade SDN 2 Werdi Bhuwana with a total of 30 students and the control group, the fourth-grade SDN 1 Werdi Bhuwana with 31 students. In the final stage, a science knowledge competency test is given which is used to collect data, an objective test.

Tabel 3. Table of Relative Frequency Distribution Competence of IPA experiment group

\begin{tabular}{ccc}
\hline $\mathbf{X}$ & $\mathbf{F}$ & $\mathbf{F r} \mathbf{( \% )}$ \\
\hline 66 & 1 & $3,3 \%$ \\
70 & 2 & $6,6 \%$ \\
73 & 2 & $6,6 \%$ \\
80 & 1 & $3,3 \%$ \\
83 & 1 & $3,3 \%$ \\
86 & 4 & $13,3 \%$ \\
90 & 2 & $6,6 \%$ \\
93 & 7 & $23,3 \%$ \\
96 & 4 & $13,3 \%$ \\
100 & 6 & $20 \%$ \\
\hline Total & $\mathbf{3 0}$ & $\mathbf{1 0 0 \%}$ \\
\hline
\end{tabular}

From the relative frequency distribution table the lowest score is 66 and the highest score is 100. The score of 66 is obtained by 1 student, the score of 70 is obtained by 2 students, the score of 73 is obtained by 2 students, the score of 80 is obtained by 1 student, the score of 83 is obtained by 
1 student, the score of 86 is obtained 4 students, score 90 got 2 students, score 93 got 7 students, score 96 was obtained by 4 students and the highest score was 100 got by 6 students. The average score from the experimental group was 85.677 . When observing that the fourth grade SDN Gugus VIII Mengwi had a KKM 70, there were $67.70 \%$ of students who had not reached the KKM.

After being given 6 times the treatment using the Learning Cycle model that only 1 in 30 students did not fulfill the KKM or around $97 \%$ had fulfilled the KKM with the KKM, 70, this result was better than the data when making observations at SDN 2 Werdhi $63.3 \%$ of students have not reached the KKM.

Table 4. Control Group Relative Frequency Distribution Table of Science Knowledge Competencies

\begin{tabular}{ccc}
\hline $\mathbf{X}$ & $\mathbf{F}$ & $\mathbf{F r} \mathbf{( \% )}$ \\
\hline 35 & 1 & $3,2 \%$ \\
38 & 4 & $12,9 \%$ \\
61 & 2 & $6,4 \%$ \\
64 & 3 & $9,6 \%$ \\
70 & 2 & $6,4 \%$ \\
74 & 3 & $9,6 \%$ \\
80 & 6 & $19,3 \%$ \\
83 & 4 & $12,9 \%$ \\
87 & 3 & $9,6 \%$ \\
90 & 1 & $3,2 \%$ \\
93 & 1 & $3,2 \%$ \\
\hline Jumlah & $\mathbf{3 1}$ & $\mathbf{1 0 0 \%}$ \\
\hline
\end{tabular}

From the relative frequency distribution table the highest score is 93 and the lowest score is 35 . The score of 35 is obtained by 1 student, the score of 38 is obtained by 4 students, the score of 61 is obtained by 2 students, the score of 64 is obtained by 3 students, the score of 70 is obtained by 2 students, A score of 74 was obtained by 3 students, a score of 80 was obtained by 6 students, a score of 83 was obtained by 6 students, a score of 87 was obtained by 3 students, a score of 90 was obtained by 1 student, a score of 93 was obtained by 1 student. At the time of observing, class four SDN Gugus VIII Mengwi had a KKM of 70 . There were $67.70 \%$ of students who had not reached the KKM. When it was made into the control class that there were 10 out of 31 students who did not fulfill the KKM or about $6.51 \%$ who had not fulfilled the KKM by using conventional learning with the KKM which was 70, this result was different from the data when making observations at SDN 1 Werdi Bhuwana $5 \%$ of students have not reached the KKM.

Based on the normality test, the experimental group obtained the score of Dhitung $=0.158$ and Dtabel Kolmogorov Smirnov $=0.240$, so Dhitung $<$ Dtabel means that the results of the experimental group's Science Knowledge Competency data are normally distributed. While the control group obtained the score of $\mathrm{D}_{\text {hitung }}=0.168$ and $\mathrm{D}_{\text {tabel }}=0.240$, then $\mathrm{D}_{\text {hitung }}<\mathrm{D}_{\text {tabel }}$ Kolmogorov Smirnov means that the data on the results of the Science Competency of Science in the control group were normally distributed.

Based on homogeinity test result $\mathrm{F}_{\text {tabel }}=1,847$ dan $\mathrm{F}_{\text {hitung }}=0,833$ it means $\mathrm{F}_{\text {hitung }}=0,862<$ $\mathrm{F}_{\text {tabel }}=1,847$ So that the data of both group have a homogent varian.

Table 5. Research Sample Hypothesis Test Results

\begin{tabular}{|c|c|c|c|c|c|c|c|c|}
\hline No & Sample & Average & Variance & dk & $\mathbf{N}$ & thitung & t tabel & Conclusion \\
\hline 1 & Experiment & 85,677 & 351,426 & & 30 & & & \\
\hline 2 & Control & 70.935 & 292,796 & 59 & 31 & 3,184 & 2,045 & $\mathrm{H}_{0}$ rejected \\
\hline
\end{tabular}

Based on the results of the t-test calculation, the results obtained $t_{\text {count }}=3.184$ with a significance level of $5 \%$ and $\mathrm{dk}=\mathrm{n} 1+\mathrm{n} 2-2=30+31-2=59$, indicating the score of $\mathrm{t}$ table $=2.045$. Based on this, it is obtained that $\mathrm{t}_{\text {count }}=3.184>\mathrm{t}$ table $=2.045$ then $\mathrm{H} 0$ is rejected, meaning that there is a significant difference in the competence of scientific knowledge of the group of students who are taught through the Learning Cycle model assisted by Audio-visual media with groups of students who are taught with the experimental model who are far apart from the group. This control shows 
that the treatment given by applying the Learning Cycle learning model assisted by audio-visual media affects the posttest results which illustrate the competence of scientific knowledge of the students themselves. The average score in the two samples, the experimental group $=85.67$ and for the control group $=70.93$. The existence of differences in science knowledge between groups taught using the Learning Cycle model assisted by audio-visual media and groups that are taught conventionally are influenced by the following factors.

First, the Learning Cycle learning model has an impact on science knowledge competencies. This Learning Cycle model has five stages, each of which arouses students' interest which makes students active in the learning process. The Learning Cycle model is student-centered, students can find their definition of the material being studied and develop it using the concepts they already have. Students learn to express ideas or ideas they have without fear. When the learning process takes place with the formation of groups, there is interaction so that they can practice the ability to work together and students can exchange ideas between friends in the group. The Learning Cycle learning model forms a relationship between existing knowledge and new knowledge possessed by students which makes learning material understood and remembered for a long time and can stimulate students to recall the subject matter they have previously obtained. The Learning Cycle learning model motivates students to be more active in learning and increase a sense of curiosity (Paramita, 2016). In the learning model, the Learning Cycle is more of a facilitator, not a provider of information, where students play an active role in finding material information learned from various existing sources. Learning Cycle learning model assisted by audio-visual media is a model that provides opportunities for students to explore the knowledge they have and present ideas or opinions that students have, independent in developing their potential, making students more active, creative, process interesting learning so that the learning process. From a boring atmosphere, a rowdy classroom atmosphere, and so on can make for an active learning atmosphere. Learning Cycle learning models to train critical thinking skills must begin to be trained so that students can develop their reasoning power in solving problems and applying the concepts that have been learned in real life. The Learning Cycle learning model can actualize and optimize students for the changes that occur (Wibowo, 2020).

Second, because it is assisted by Audio Visual media. Audiovisual media contains images so that messages and information conveyed more attracts students' attention, students can understand a concept as a whole, not only as knowledge but can also be applied in the learning process and in everyday life (M. Dewi, 2017). Audio-visual media utilizes two senses, the sense of sight and the sense of hearing, making students understand an abstract concept so that it is easily understood and remembered by students.Audio visual media is one of the media that relies on current technology. By using this media the teacher simultaneously introduces technology to students from an early age. Learning using audiovisual media provides a new atmosphere for students so that it has an impact on student activity and enthusiasm for learning. This concurs with research (Jais, 2020) Using Audio-Visual media can improve learning outcomes for elementary students.

The three Learning Cycle models assisted with audio-visual media make the learning process active and fun because they are combined with audio-visual media. The learning process using the Learning Cycle learning model assisted by audio-visual media can help students more easily understand abstract science learning concepts. Learning activities like that students can develop skills in carrying out scientific communication in discussion activities so that learning becomes active and not boring. Cycle learning model assisted by audio-visual media is a model that provides opportunities for students to explore the knowledge they have and present ideas or opinions that students have to be independent in developing their potential. This is reinforced based on the results of research conducted by research by (Ariesta, 2020) that there is an influence of the Learning Cycle learning model on Primary School Student Learning Outcomes, making students active during the learning process. In line with research (Resty, 2017) The Learning Cycle Learning Model or learning cycle which has five stages improves SD science learning outcomes because it creates fun classes and makes students active during the learning process.

The difference in scientific knowledge can be seen from the learning process that has been implemented in the two sample groups, the results of hypothesis testing, and is seen based on the mean score in the experimental group and the control group. Based on this explanation, it can be said that the Learning Cycle learning model assisted by Audio Visual media affects the competence of science knowledge in fourth-grade students of SDN Gugus VIII Mengwi for the 2019/2020 academic year. 


\section{Conclusion}

Conclusions can be submitted as follows; The average score of the science knowledge competency of the group that was taught using the Learning Cycle model using audio-visual media was higher than the group that was taught conventionally. The group that was taught through the Learning Cycle model assisted by audio-visual media had an average of 85.677 and the group that was taught conventionally had an average of 70.935. The results of hypothesis testing with t-test score $t=3.184$ and a significance level of $5 \%$ and $d k=59$ obtained $t$ table $=2.045$ so that $t=3.184>$ t table $=2.045$. Based on the testing criteria, $\mathrm{HO}$ is rejected and Ha is accepted, which states that there is a significant difference in the competence of scientific knowledge between the groups that are taught through the Learning Cycle learning model assisted by audio-visual media and those that are taught conventionally in the fourth grade of SDN Gugus VIII, Kecamatan Mengwi, Academic Year 2019 / 2020. This difference is due to the influence of the Learning Cycle learning model assisted by audio-visual media. It can be concluded that there is a significant effect of the Learning Cycle learning model assisted by audio-visual media on the fourth-grade science competency of SDN Gugus VIII, kecamatan Mengwi, Academic Year 2019/2020. Suggestions to several parties, Teachers can use various kinds of learning models, such as the Learning Cycle model. The principal supports teachers to improve the quality of the implementation of learning. The suggestion to students is to study diligently and diligently to achieve their goals. To Other Research This research is used as reference material in carrying out further research so that it gets a more diverse subject.

\section{References}

Aditya, D. (2019). Pengaruh Model Pembelajaran Learning Cycle (5e) Berbasis Kearifan Lokal Terhadap Sikap Disiplin Belajar Dan Hasil Belajar IPA Siswa Kelas IV SD Gugus V Kecamatan Sukasada. Jurnal Pendidikan Multikultur Indonesia, 2(1). http://dx.doi.org/10.23887/jpmu.v2i1.20792

Agung, A. A. . (2014). Buku Ajar Metodologi Penelitian Pendidikan. Aditya Media Publishing.

Amanda, B. (2017). Pengaruh Model Pembelajaran Kooperatif Tipe Talking Stick Terhadap Kompetensi Pengetahuan IPA. MIMBAR PGSD Undiksha, 5(2). http://dx.doi.org/10.23887/jijpgsd.v5i3.12426

Ariesta, M. (2020). Pengaruh Model Learning Cycle 5e Berbantuan Media Benda Konkret. Progres Pendidikan, 1(1). http://prospek.unram.ac.id/index.php/PROSPEK/article/view/5

Astuti, S. (2017). Pengaruh Model Pembelajaran Talking Stick Berbasis Concept Song Terhadap Kompetensi Pengetahuan IPA. MIMBAR PGSD Undiksha, 5(2). http://dx.doi.org/10.23887/jipgsd.v5i2.10835

Barahudin, $\quad$ A. (2014). Siklus Belajar (Learning Cycle). https://afidburhanuddin.wordpress.com/2014/06/07/siklus-belajar-learning-cycle/

Barus, R. T. (2019). Penerapan Metode Outdoor Study Dalam Pembelajaran IPA Untuk Meningkatkan Hasil Belajar Siswa Kelas IV SD Negeri 053963 Raja Tengah Tahun Ajaran 2018/2019. Digital Repository Universitas Quality. http://portaluniversitasquality.ac.id:55555/id/eprint/439

Devitasari, T. (2019). Keefektifan Model SAVI Terhadap Minat dan Hasil Belajar IPA SDN Lawatan 01 Kabupaten Tegal. IIdonesian Journal of Conservation, 8(1). https://journal.unnes.ac.id/nju/index.php/ijc/article/view/22681

Dewi. (2013). Pengaruh Model Pembelajaran Siklus Belajar (Learning Cycle) 5e Terhadap Hasil Belajar Ipa Siswa Kelas V SDN 26 Pemecutan Denpasar Barat. MIMBAR PGSD Undiksha, 1(1). http://dx.doi.org/10.23887/ijpgsd.v1i1.1207

Dewi, A. (2017). Pengaruh Model Pembelajaran Learning Cycle Terhadap Penguasaan Kompetensi Pengetahuan IPA Siswa Kelas IV SD Gugus Untung Surapati Denpasar Timur Tahun Ajaran 2016/2017. MIMBAR PGSD Undiksha, 5(2). http://dx.doi.org/10.23887/ijpgsd.v5i2.10771

Dewi, J. M. (2017). Pengaruh Model Pembelajaran Problem Based Learning Berbantuan Media Audio Visual Animasi Terhadap Hasil Belajar IPA. MIMBAR PGSD Undiksha, 5(2). http://dx.doi.org/10.23887/ijpgsd.v5i2.10657 
Dewi, S. (2018). Pengaruh Model Pembelajaran Learning Cycle5e Berbantuan Media Lingkungan Terhadap Kompetensi Pengetahuan IPA. Jurnal Penelitian Dan Pengemabangan Pendidikan, 2(2). http://dx.doi.org/10.23887/jppp.v2i2.15389

Jais, Y. (2020). Pengaruh Penerapan Model Siklus Belajar (Learning Cycle)5e Dengan Memanfaatkan Media Audio Visual Terhadap Hasil Belajar IPA SD. Jurnal PEndidikan Dasar, 1(1). https://ejournal.iainkendari.ac.id/diniyah/article/view/1817

Karunia, Fatwa Suci. (2017). Pengembangan Media Pembelajaran Berbasis Macromedia Flash 8 Pelajaran IPA Materi Energi Listrik Kelas VI Di SD. Institutional Repository. http://eprints.umm.ac.id/35617/

Kusuma, J. (2018). Penerapan Model PJBL Berbantuan Media Audiovisual Untuk Meningkatkan Hasil Belajar IPA. Jurnal Ilmiah Pendidikan Profesi Guru, 1(1). http://dx.doi.org/10.23887/jippg.v1i1.14263

Muakhirin, Adi. (2014). Peningkatan Hasil Belajar IPA Melalui Pendekatan Pembelajaran Inkuiri Pada Siswa SD. Jurnal Ilmiah GOru 1. https://journal.uny.ac.id/index.php/cope/article/view/2933

Nismalasari, S. (2016). Penerapan Model Pembelajaran Learning Cycle Terhadap Keterampilan Proses Sains Dan Hasil Belajar Siswa Pada pokok Bahasan Getaran Harmonis. EduSains, 4(2). https://doi.org/10.23971/eds.v4i2.511

Nurbani, D. (2016). Pengaruh Model Learning Cycle Terhadap Keterampilan Proses Sains Siswa SD Kelas IV Pada Materi Hubungan Antara Sifat Bahan Dengan Kegunaannya. Jurnal Pena Ilmu, 1(1). https://doi.org/10.23819/pi.v1i1.3301

Paramita, Y. (2016). Pengaruh Learning Cycle 5e Terhadap Hasil belajar IPA Kelas V SD Gugus IV Pupuan. MIMBAR PGSD Undiksha, 4(1). http://dx.doi.org/10.23887/jipgsd.v4i1.6950

Pradnyandari, M. (2014). Pengaruh Model Pembelajaran Talking Stick Berbasis Concept Mapping Terhadap Hasil Belajar IPA. MIMBAR PGSD Undiksha, 2(1). http://dx.doi.org/10.23887/jijpgsd.v2i1.3011

Putriani, D. (2016). Pengaruh Model Pembelajaran Learning Cycle 5E Berbantuan Media GrafisTerhadap Hasil Belajar IPA pada Siswa Kelas IV SD Gugus Majapahit Kecamatan Pekutatan Kabupaten Jembrana Semester Genap Tahun Pelajaran 2015/2016. MIMBAR PGSD Undiksha, 4(1). http://dx.doi.org/10.23887/ijpgsd.v4i1.7482

Rahayu. (2019). Penerapan Model Pembelajaran Learning Cycle-5E Dalam Pembelajaran IPA. Buta Aksara.

Resty, C. (2017). Pengaruh Model Siklus Belajar 5E Terhadap Hasil Belajar IPA Siswa Kelas IV SDN Gugus Kompyang Sujana Kecamatan Denpasar Barat Tahun Ajaran 2016/2017. MIMBAR PGSD Undiksha, 5(2). http://dx.doi.org/10.23887/ijpgsd.v5i2.10777

Rositayani. (2018). Pengaruh Model Pembelajaran Children's Learning in Science Berbantuan Media Audio Visual Terhadap Kompetensi Pengetahuan IPA. Jurnal Ilmiah Sekolag Dasar, 2(3). http://dx.doi.org/10.23887/jisd.v2i3.16150

Saharudhin, A. (2018). Meningkatkan Hasil Belajar IPA Siswa Kelas IV-B Melalui Pemanfaatan Media Audio-Visual (Film Projector) SD Negeri Kompleks IKIP 1 Kota Makassar. Jurnal Ilmu Pendidikan, Keguruan Dan Pembelajaran, https://doi.org/10.26858/pembelajar.v2i2.7098

Setiawan, P. (2017). Pengaruh Model Pembelajaran Learning Cycle 5e Berbantuan Mind Mapping Terhadap Hasil Belajar Matematika. MIMBAR PGSD Undiksha, 5(2). http://dx.doi.org/10.23887/jjpgsd.v5i2.10841

Suarni, N. K. (2013). Pengaruh Model Pembelajaran Learning Cycle Berbasis Media Lingkungan Alam Terhadap Hasil Belajar IPA Siswa Kelas V SDN 5 Pedungan Denpasar. MIMBAR PGSD Undiksha, 1(1). http://dx.doi.org/10.23887/jipgsd.v1i1.1554

Sugiyono. (2018). Metode Penelitian Kuantitatif, Kualitatif, dan R \& D. Alfabeta. 
Sulthon. (2012). Meningkatkan Hasil Belajar Siswa Dengan Model Siklus Belajar (Learning Cycle 5e)Berbasis Eksperimen Pada Pembelajaran Sains Di SDN Patrang I Jember. Jurnal Ilmu Pendidikan Sekolah Dasar, 1(2), 16. http://pgsd.fkip.unej.ac.id/wpcontent/uploads/sites/5/2015/05/Jurnal-IIPSD-Vol-1-No-2-2012.1.pdf\#page=16

Suryani, N. (2017). Pengaruh Model Pembelajaran Learning Cycle Berbantuan Media Audio Visual Terhadap Kompetensi Pengetahuan IPA Siswa Kelas IV. MIMBAR PGSD Undiksha, 5(2). http://dx.doi.org/10.23887/jijpgsd.v5i2.10803

Taung, R. (2014). Penerapan Experiential Learningdalam Pembelajaran IPA Pada Materi Ciri Khusus Makhluk Hidup Untuk Meningkatkan Hasil Belajar Siswa Kelas VI SDN Inpres Mandok. Jurnal Kreatif Tadulako Online, http://jurnal.untad.ac.id/jurnal/index.php/JKTO/article/view/2817

2(2).

Wibowo, N. (2020). Keefektifan Model Learning Cycle Berbantuan Media Audiovisual Terhadap Hasil Belajar Siswa Tema Selalu Berhemat Energi. Jurnal Penelitian Dan Pengembangan Pendidikan, 4(1). http://dx.doi.org/10.23887/jppp.v4i1.25013

Wijayanti, D. (2017). Pengaruh Model Pembelajaran Kooperatif Tipe Talking Stick Berbantuan Media Audio Visual Terhadap Hasil Belajar IPS. MIMBAR PGSD Undiksha, 5(2). http://dx.doi.org/10.23887/ijpgsd.v5i2.11015 